\title{
Practice of Islamic Financial Management in Bangladesh: Evidence from Islamic Banks
}

\author{
Serajul Islam \\ Associate Professor \\ Department of Business Administration \\ International Islamic University Chittagong \\ Kumira, Sitakunda, Chittagong-4318, Bangladesh \\ E-mail Address:serajulislamiiuc@gmail.com \\ Mobile Number: 088-01711448142 \\ Tania Sultana \\ Lecturer \\ Department of Business Administration \\ International Islamic University Chittagong \\ Kumira, Sitakunda, Chittagong-4318, Bangladesh \\ E-mail Address:taniasultanaiiuc@gmail.com
}

Received:January 1, 2018

Accepted:January 10, 2019

Online Published:January 17, 2019

\begin{abstract}
The growing awareness of the systemic importance of Islamic banking and finance to the development has prepared the ground for the work of upgrading the existing Islamic banking practices. Hence, this study aims to evaluate the Islamic Financial Management (IFM) practices of Islamic banks in Bangladesh. In line with the objective of the study, several ratio analyses were conducted based on ANNOVA test and the sample size includes 8 Islamic banks from 2007 to 2013.The findings revealed that the Islamic banks in Bangladesh are homogenous; however, they are not financially healthy when liquidity measurements are concerned. Additionally, capital structure efficiency results revealed that most of the Islamic Banks in Bangladesh are practicing debt-based financing rather than equity. While the study has observed that the practices of IFM in Bangladesh are promising, however, there are numerous challenges encroaching the industry. Hence, immediate attention from the respective authorities, including practitioners and policy makers are indeed vital.
\end{abstract}

Keywords:Islamic Banks, Islamic Financial Management, Efficiency, Ratio.

\section{Introduction}

In the recent era, Islamic banking and finance becomes an important topic both in the academic literature and among practitioners since it represents a new reality to the conventional banking practices (Sundararajan \&Errico, 2002; Khan \& Ahmed, 2001). This is mainly due to the fact that Islamic banking and finance aims to provide justice, honest and fairness to all parties in any financial transaction by ensuring that their rights and dues are preserved accordingly (Abu-Tapanjeh, 2009). Another major ethical component of this system is that Islamic financial institutions (Islamic banks) are less risky due to the elimination of interest-based transactions. As a result of this uniqueness in Islamic banking and finance, it has progressed in many economies during the last few decades, including Bangladesh.

Several researchers have examined the reasons behind such spectacular growth of the Islamic banking and finance industry. Such as, Iqbal, Ahmad and Khan (1998) found that the rapid growth in Islamic finance and banking in Muslim countries, and around the world during the last twenty years is influenced by the introduction of broad economic and structural reforms in financial systems, the liberalization of capital movement, privatization, the 
global integration of financial markets, and the introduction of innovative and new Islamic financial products. Furthermore, Islamic banking instruments are also based on "trade financing instruments" that is developed on mark-up arrangements fueled the growth (Sundararjan\&Erico, 2002; Fiennes, 2007;Akkizidis\&Khandelwal, 2007; Khan \& Bhatti, 2008).

However, criticisms also raised related to Islamic banking and finance. For example, Fiennes (2007) pointed out that Islamic banks are like conventional banks, they also have similar characteristics, such as, credit risk, market risk, and operational risks. Opponents of the Islamic banking and finance have argued that Islamic banking instruments are riskier because their products and services are relatively new compared to the conventional banking services. This is also corroborated by the findings of Khan and Ahmed (2001); Sundararajan and Errico (2002) that Islamic banks are facing a unique nature of risks due to a particular structure of its balance sheets as the operational principles are different compared to the conventional banking practices.

Additionally, Mohiuddin (2004) also identified ten important constrains related to Islamic banking and finance concept and its practices in the global arena. Among these constrains, absence of Islamic administration in the state level, scarcity of research outcomes on Islamic management, lack of research-based publications, lack of integration of Islamic banking and finance curricula at the university level, lack of ideal Islamic banking and finance organizations, and almost no effort to combine the conventional and Islamic management.

Due to these criticisms, it has led us to investigate on Islamic Financial Management (IFM), which is one of the core elements in such banking system. While it is notoriously difficult to precisely define what IFM is, however, it captures almost all segments of Islamic banking and finance operations. Based on the existing literature, IFM can be defined as a distinct social process consisting of forecasting and Islamic planning, major investment and financing decisions, coordination and control, dealing with Islamic financial markets, and risk management designed to raise capital from proper sources allowed by Islamic Shariah in order to minimize cost of capital and to invest the capital optimally through the Islamic modes of investment in the feasible projects to maximize stakeholders' benefits. From the definition, it is clear that all activities of an organization and their day to day activities are included in the IFM.

The context of Islamic banking and finance in Bangladesh is not different. Bangladesh is considered as one of the third largest Muslim country in the world with around 160 million populations, of which 90 percent are Muslim. The hope and aspiration of the vast majority of Muslim population to run banking system on the basis of Islamic principle came into reality after the OIC recommendation at its foreign ministers meeting in 1978 at Senegal to develop separate Islamic banking system. After 5 years of that declaration, in 1983, Bangladesh established its first Islamic bank (Islami Bank Bangladesh Limited-IBBL). Since then, the Islamic banking and finance industry has seen a remarkable progress domestically.

Till today, there are eight full-fledged Islamic banks out of 56 scheduled banks, six Islamic insurance companies out of 62 insurance companies, and four Islamic non-banking financial institutions out of 33 are found to be practicing IFM in Bangladesh. However, there are some additional financial institutions as well that practices IFM in a limited scale in its operation. Since IFM remains a lucrative solution to the conventional financial system, this study mainly focuses on the practice of IFM in Islamic banks.

The rest of this paper is structured as follows. Section two provides the data and methodology, section three analyses and discusses the findings and finally section four concludes the study.

\section{Brief Literature Review}

The history of Islamic banking and finance, as well as IFM was not first started in Bangladesh; rather Bangladesh has adopted some of the practices from different countries. Therefore, it would be useful to focus on the development of Islamic banking and finance from the global perspective through historical narratives. Hence, this section overview the existing literature related to the objective of the study.

2.1 A Brief Overview of Islamic Banking and Finance: Global Perspective

Islamic financial system, particularly Islamic banking and finance is not a new concept rather existed since the initial and spreading period of Islam. The evaluation of the Islamic banking can be classified into three eras.

The first era began from the early years of Islam till the period of Caliph ar-Rashedin. During this era, deposit/savings (safe keeping of money and valuable items) and loan (qard) were exercised. For example, the wealthy people used to keep their money and valuable items to the most trustworthy person, Prophet Muhammad (p.b.u.h.) at that time. This is because, the depositors would choose persons with honesty and sincerity in keeping and returning their valuable items. Apart from these, the practicing of barter (exchange goods or services for other goods or services without using money) evidenced in the following Hadith narrated by Abu al-Minhal: "I asked alBara bin Azib and Zaid bin Arqam about practicing money exchange. They replied, "we are traders in the time of Allah's apostle (p.b.u.h.) and I asked Allah's Apostle about money exchange. He replied, "if it is from hand to hand, there is no harm in it,' otherwise it is not permissible", (Khan, 1989, p-157). 
The second era started from the era of the caliphates until the fall of the Uthmaniyah Empire. This era witnessed the continuation of banking activities practiced in the early era. For instance, trading activities carried out in Basrah (presently a city in Iraq) with cheque instead of money. Although Islamic finance failed to expand during this period, however, development took place in terms of legal maxim (fatwa) by Muslim jurists pertaining to issues of financial transaction (muamalat), particularly those involving usury (riba). Many renowned scholars (jurists/ ulama) established their school of thought such as Imam al-Azam Abu Hanifah (698-7670), Imam Malik ibn Anas (712795), Imam Ahmad ibn Hambal (778-855) and al-Shafil (767-820) during this phase. The views of these jurists, particularly on Muamalat, have been used as a reference for taking any decision pertaining to Islamic financial activities. This includes whether a conduct is lawful and in accordance with Shariah principles or otherwise.

Finally, after the second phase, the revolutionary modern era of banking and finance has started (Sudin\&Nursofiza, 2009). In this era, the first Islamic financial institution has been established in the Indian subcontinent during the 1940s (Laldin, 2008). After that, an Islamic bank was made in Pakistan in the 1950s. Further, the development of the Islamic financial system started with the establishment of the Pilgrimage Fund known as 'Tabung Haji' of Malaysia, a first formal Islamic savings institution that started in 1963 (Erol\& El- Bdour, 1989). However, MitGhamr savings bank, an experimental bank of Islamic banking in Egypt, was started in 1963, and paved the way for the establishment of other Islamic banks in the region. The list of Islamic banks in different countries with establishment year is in the following Table 1.

Table 1: List of Islamic Banks with Year of Establishment (1970s-1980s)

\begin{tabular}{|c|c|c|c|}
\hline S.L. & Name & Country & $\begin{array}{l}\text { Year of } \\
\text { establishment }\end{array}$ \\
\hline 01 & Nasser Social Bank & Egypt & 1972 \\
\hline 02 & Islamic Development Bank & Saudi Arabia & 1975 \\
\hline 03 & Dubai Islamic Bank & United Arab Emirates & 1975 \\
\hline 04 & Faisal Islamic Bank of Egypt & Egypt & 1977 \\
\hline 05 & Faisal Islamic Bank of Sudan & Sudan & 1977 \\
\hline 06 & Kuwait Finance House & Kuwait & 1977 \\
\hline 07 & Islamic Banking System International Holdings & Luxembourg & 1978 \\
\hline 08 & Jordan Islamic Bank & Jordan & 1978 \\
\hline 09 & Bahrain Islamic bank & Bahrain & 1979 \\
\hline 10 & Dar al-Mal al-Islami & Switzerland & 1981 \\
\hline 11 & Bahrain Islamic Investment Company & Bahrain & 1981 \\
\hline 12 & $\begin{array}{lllll}\text { Islamic International Bank for Investment and } \\
\text { Development }\end{array}$ & Egypt & 1981 \\
\hline 13 & Islamic Investment House & Jordan & 1981 \\
\hline 14 & Albaraka Investment and Development Company & Saudi Arabia & 1982 \\
\hline 15 & Saudi-Philippine Islamic Development Bank & Saudi Arabia & 1982 \\
\hline 16 & Bank Islam Malaysia Berhad & Malaysia & 1983 \\
\hline 17 & Islamic Bank Bangladesh Limited & Bangladesh & 1983 \\
\hline 18 & Islamic Bank International & Denmark & 1983 \\
\hline 19 & Tadamon Islamic Bank & Sudan & 1983 \\
\hline 20 & Qatar Islamic Bank & Qatar & 1983 \\
\hline 21 & Bait Ettamouil Saudi Tounsi & Tunisia & 1984 \\
\hline 22 & West Sudan Islamic Bank & Sudan & 1985 \\
\hline 23 & Albaraka Turkish Financial House & Turkey & 1985 \\
\hline 24 & Faisal Finance Institution Inc. & Turkey & 1985 \\
\hline 25 & Al-Rajhi Company for Currency Exchange \& Commerce & Saudi Arabia & 1985 \\
\hline 26 & $\begin{array}{l}\text { Al-Ameen Islamic and Financial Investment Corporation } \\
\text { India Limited }\end{array}$ & India & 1985 \\
\hline
\end{tabular}

Source: Haron\&Shanmugam (1997)

\subsection{Overview of Islamic Banking Industry in Bangladesh}

First of all, the financial sector in Bangladesh is classified into three broad categories based on regulation:

- Formal sector

- Semi-formal sector and 
- Informal sector.

Among this financial sector, banking sector, which is the major part of formal financial sector dominants other types of financial institutions in the industry. Due to its significant effect in the economy of Bangladesh, banking industry is highly regulated and monitored by the Bangladesh Bank (BB), the central bank of Bangladesh. Though Bangladesh inherited an interest-based banking system since its independence, the first Islamic bank, Islami Bank Bangladesh Limited (IBBL), was established in 1983. In 2017, out of 57 banks in Bangladesh, eight private commercial banks (PCBs) operated as full-fledged Islamic banks and 16 conventional banks (including three foreign commercial banks-FCBs) were involved in Islamic banking activities through window Islamic banking.

The Islamic banks have continued to show strong growth since its inception, as reflected by the increasing market share of the Islamic banking sector in terms of assets, financing and deposits compared to the total banking system. A brief analysis on the performance of Islamic banks is given in Table 2. It is evident from the Table 2 that, total deposits of the Islamic banks and Islamic banking branches and windows of the conventional banks stood at BDT 1857.3 billion at the end of December 2016 which accounted for 20.79 percent of total deposits (BDT 8933.92 billion). Total credit of the Islamic banks and the Islamic banking branches and windows of the conventional banks stood at BDT 1647.0 billion at the end of December 2016 which accounted for 24.44 percent of total credit (BDT 6739.3 billion) of the banking system in Bangladesh.

Table 2: The basic indicators of Islamic banks in Bangladesh (BDT in Billion)

\begin{tabular}{|c|c|c|c|c|c|c|c|c|}
\hline \multirow[t]{2}{*}{ Particular } & \multicolumn{2}{|c|}{$\begin{array}{l}\text { Full-fledged } \\
\text { Islamic Banks }\end{array}$} & \multicolumn{2}{|c|}{$\begin{array}{c}\text { Window Islamic } \\
\text { banks }\end{array}$} & \multicolumn{2}{|c|}{ All Islamic Banks } & \multicolumn{2}{|c|}{ All banks } \\
\hline & 2016 & 2015 & 2016 & 2015 & 2016 & 2015 & 2016 & 2015 \\
\hline Number of banks & 8 & 8 & 16 & 16 & 24 & 24 & 57 & 56 \\
\hline Deposits & 1770.7 & 1552.2 & 86.6 & 89.4 & 1857.3 & 1641.6 & 8933.9 & 8033.5 \\
\hline Credits & 1565.0 & 1305.5 & 82.0 & 81.7 & 1647.0 & 1387.2 & 6739.2 & 5952.9 \\
\hline Investment deposit ratio \%) & 86.3 & 83.2 & 84.2 & 75.6 & 86.7 & 82.7 & 71.85 & 70.98 \\
\hline Liquidity* & 113.6 & 133.4 & 3.0 & 3.1 & 116.6 & 136.5 & 1259.5 & 1234.1 \\
\hline
\end{tabular}

* Excess (+)/shortfall (-): Conventional banks which have Islamic banking branches and windows do not maintain Statutory Liquidity Ratio (SLR) individually, but their head offices of the respective banks maintain a combined SLR and liquidity position.

Sources: Bangladesh Bank

Islamic banks in Bangladesh receive deposit under two principals: a) Al-Wadeeah or current account and b) Mudaraba or savings account. Under Mudaraba, most Islamic banks have the following deposit scheme:

- Mudaraba Savings Deposits (MSD)

- Mudaraba Short Notice Deposits (MSND) and

- Mudaraba Term Deposits (MTD)

One of the uniqness of Islamic banking system is that Islamic banks do not directly deal with money rather they run business with money. The funds of Islamic banks in Bangladesh are mainly invested in the following modes:

- Mudaraba;

- Musharaka;

- Bai-Murabaha (Murabaha to the purchase orders);

- Bai-Muajjal;

- Salam and parallel Salam;

- Istisna and parallel Istisna;

- Ijara;

- IjarahMuntahiaBittamleek (Hire Purchase);

- Hire Purchase MusharakaMutanaqisa (HPMM);

- Direct Investment;

- Investment Auctioning;

- Quard and

- Quard Hassan.

2.3. Issues and Challenges of IFM

Despite having a considerable expansion in terms of number of IFI and its branches along with the client based in most of the Muslim majority country, the sector has encroached with several issues and challenges (few of them are highlighted above) that have hindered the potential growth of the sector in Bangladesh. 
Among some of the problems and issues facing by the Islamic banking and finance industry and IFM in particular, Ather (2007) highlighted several crucial issues. The issues are mostly related to managerial functions, Islamic planning and organizing, Islamic management, motivation under Islamic management and control system and, regulatory and legal aspects. Iqbal, Ahmad and Khan (1998) classified challenges of Islamic Banking in two ways; Islamic banking institutional aspects and Islamic Banking operational aspects. Challenges of institutional aspects are as follows:

- Islamic banks suffer from the lack of institutional support. Building a proper institutional set up is most serious challenge for the Islamic finance.

- Lack of appropriate legal framework and supportive policies

- Lack of effective supervisory framework

- Lack of Accounting Standards Boards for Islamic finance practicing companies

- Lack of equity institutions

- Establishment of organised secondary financial markets

- Necessity to have a market for short term placements of funds

Usmani (1998) has highlighted the problems of Islamic banking and identified three types of important challenges; i) capital budgeting, ii) financing and iii) working capital management. On the other hand, Akkas (2008) categorized challenges into two ways; i) macro operational challenges and ii) micro operational challenges. Problems related with macro operation are: liquidity and capital, valuation of banks assets, credit creation and monetary policy, financial stability, the ownership of banks, lack of capital market and financial instruments, insufficient legal protection. In contrast, problems related to micro operation of Islamic banks are increased cost of information, control over cost of funds, mark-up financing, excessive resort to the murabaha mode, utilization of interest rate for fixing the profit margin in murabaha sales, financing social concern, lack of positive response to the requirement of government financing.

On top of that, there are few other issues that have hindered the growth of the IFM practices in most of the countries including Bangladesh. Firstly, in the era of globalization and rapid development, there is still a lack of sufficient infrastructures for Islamic trade financing on an international basis. This is significantly important as the international trade has gained momentum in most of the developing countries both in terms of import and export. As a result of this, the Islamic banking requires competitive financial products and services to cater the growing demand of exporters/importers in a majority of the Muslim countries and, Bangladesh in particular.

Secondly, the practices of Islamic banking and finance, and IFM in particular require conformity of both the national conventional laws and Shariah rules. Without the cooperation of these both institutions that implement these two types of laws in a country, achieving the expected growth in the esteemed sector would not be possible. However, it is observed that these two segments of the government in majority of the cases are in non-conformity, hence raising several issues and challenges to practically implement in the country.

Third, Islamic banking and finance is part of the financial sector of a country, hence, corporate sector plays an important role in this context. Similarly, there should be coexistence of both the Islamic banking and finance along with the corporate sector for sustainable development of an economy. However, it is understood that the corporate sector in Bangladesh is still rather poor, and no adequate supports are given to this industry in an aim to promote IFM in the country. Fourth, surprising enough, although the majority of the people in Bangladesh are Muslim and the country's economy is booming in the recent decade as well as considerable size of the Islamic banking and finance industry, unfortunately, there is no Islamic capital market exist as of yet. However, countries like Malaysia have its own Islamic capital market (Oseni\& Hassan, 2012).

Fifth, since the history of Islamic banking and finance is not old and still in its beginning/growth stage in most of the Muslim countries including Bangladesh, there is a lack of professionals that are conversant with IFM. Due to the shortage of the professionals, the sector experienced significant turbulence in its growth path. In a seminal work recently in Dhaka, one of the authority in a think tank reported that "To ensure true benefit from Islamic banking practices, we need to concentrate more on the concept and need to develop human resources with adequate knowledge of Islamic banking" (The Financial Express, 2018).

Sixth, the successful and effective Islamic banking and finance practices requires that both the supplier and creditor of a loan contract uphold the rules and regulations prescribed for the financial transaction. However, a bitter truth is that, there are a mounting of loan defaulters, at least, 230,000 in Bangladesh as of 2018, reported by the country's finance minister that dry out funds from the financial industry (Dhaka Tribune, 2018). This is also a great obstacle for the industry to perform efficiently and progress well in their operation. Lastly, as described initially, the Islamic banking and finance sector has a lack of supportive institutions and instruments, which is considered as an important determinant to promote IFM practices in the country. 


\section{Data and Methodology}

\subsection{Data}

Since the focus of the thesis is to analyse the various dimensions of IFM practices in Islamic Banks in Bangladesh, the study explored several databases and online resources to identify the population at the first hand. Then, the study screened through each and every institution before choosing them in the analysis. Basic rules were imposed while selecting the sample, such as, whether the institution has an annual report, which year it was established and also the availability of the basic institutional data. After the careful assessment, the study ended up with seven full-fledged Islamic banks currently operating in Bangladesh and they meet the imposed criteria. They are, Islami Bank Bangladesh Limited, ICB Islamic Bank Limited, Al-ArafahIslami Bank Limited, Social Islami Bank Limited, ShahjalalIslami Bank Limited, Export Import Bank of Bangladesh Limited, First Security Islami Bank Limited and Union Bank Limited

Since, all the Islamic banks and insurance companies were taken as the sample for the study, thus, we have sufficient confidence that the sample size chosen has covered the full population. The study covered the annual reports of the sample companies for 7 years, which is basically a longitudinal dataset, from 2007 to 2013.Collecting data from the secondary source was not an easy process for this study. However, the important sources of secondary data include annual reports of the selected Islamic Banks and Islamic insurance companies. To validate and standardized the data, both the hard and soft copy of annual reports of Islamic banks and Islamic insurance companies for cross checking to minimize the errors. Hence, the study believes that a very good quality of dataset has been used in the analysis. Hence, the findings and policy implications derived from the analysis are believed to be consistent and robust.

\subsection{Methods}

The data and information collected and processed manually to make it workable in software such as SPSS 20.0. The study used various statistical techniques. Analysis of Variance, known as ANOVA, is a statistical technique used to analyse the differences among group means in a sample more specifically, the one-way ANOVA to analyse the differences of various financial performance of Islamic banks. The following section will provide a brief description of the performance assessed in the study.

To examine the performance among Islamic banks, the study looked at several financial aspects, such as working capital management efficiency, capital structure efficiency, capital budgeting efficiency, and overall IFM operating efficiency in line with the definition of the IFM. To analyse the performance, each of the criteria employed several other sub-categories to have a better statistical result. To capture working capital management efficiency, current ratio, quick ratio, cash ratio and receivables turnover are used. Then, the study analyses capital structure efficiencies of the Islamic banks by using the Debt Ratio. After that, focusing on capital budgeting efficiency, the study relied on Fixed Asset Turnover Ratio. The last aspects of IFM's operating efficiency and effectiveness are measured by several profitability ratios, namely, Profit Margin Ratio (PMR), Return on Assets (ROA) and Return on Equity (ROE).

\section{Data Analysis and Discussion}

Table 3 shows the result of current ratio of Islamic banks in Bangladesh and the comparison among them using ANOVA. The findings show that on average Al ArafahIslami Bank Limited (AAIBL) maintains the highest current ratio (1.51) over the year 2007 to 2013 followed by Islami Bank Bangladesh Limited (IBBL) (1.42) and ICB Islami Bank Limited (ICBIBL) (1.28). The mean current ratio of the seven selected Islamic banks $(1 \leq \mu \leq 1.51)$ shows that short term solvency of the banks is quite satisfactory. All the Islamic banks seem to have reasonably enough liquid assets with the exemption of Export Import Bank of Bangladesh Limited (EXIM) bank. Hence, it is highly likely that the Islamic banks are capable of settling their financial obligations and, thus avoid experiencing financial distress.

The findings of the results are in line with Olson and Zoubi (2008), which suggested that Islamic banks hold more cash relative to deposits and less relative to assets than conventional banks. The standard deviation (o) lies from 0.02 to 0.66 . This finding suggests that variations of current ratios of the Islamic banks are reasonably lower over the seven years periods. One important finding emerged from this table is that, on the basis of current ratio, there is no sign of difference among the Islamic banks. These suggest that Islamic banks in Bangladesh are homogeneous and performing in a similar pattern when current ratio is considered. 
Table 3: Current ratios of Islamic banks in Bangladesh

\begin{tabular}{|c|c|c|c|c|c|c|c|c|c|c|}
\hline Banks & 2007 & 2008 & 2009 & 2010 & 2011 & 2012 & & 2013 & Mean & STDEV \\
\hline AAIBL & 1.01 & 1.01 & 1.00 & 1.36 & 2.58 & 2.30 & & 1.33 & 1.51 & 0.66 \\
\hline EXIM & 0.65 & 0.86 & 1.08 & 1.12 & 1.12 & 1.11 & & 1.10 & 1.00 & 0.18 \\
\hline IBBL & 1.48 & 1.40 & 1.37 & 1.50 & 1.45 & 1.38 & & 1.37 & 1.42 & 0.05 \\
\hline FSIBL & -- & 1.20 & 1.12 & 1.12 & 1.15 & 1.16 & & 1.14 & 1.15 & 0.03 \\
\hline SIBL & 1.01 & 1.22 & 1.25 & 1.22 & 1.24 & 1.21 & & 1.21 & 1.19 & 0.08 \\
\hline SJIBL & 1.24 & 1.24 & 1.23 & 1.23 & 1.27 & 1.27 & & 1.23 & 1.24 & 0.02 \\
\hline ICBBL & 1.42 & 1.37 & 1.36 & 1.28 & 1.33 & 1.13 & & 1.10 & 1.28 & 0.12 \\
\hline \multicolumn{11}{|c|}{ ANOVA } \\
\hline & & & & & $\begin{array}{l}\text { Sum of } \\
\text { Squares }\end{array}$ & Df & & $\begin{array}{l}\text { Mean } \\
\text { Square }\end{array}$ & $\mathrm{F}$ & Sig. \\
\hline \multirow{3}{*}{$\begin{array}{l}\text { Current } \\
\text { banks }\end{array}$} & \multirow{3}{*}{ ratios of the } & sample & \multicolumn{2}{|c|}{ Between Groups } & .000 & & 6 & .000 & .000 & 1.000 \\
\hline & & & \multicolumn{2}{|c|}{ Within Groups } & 196.000 & & 42 & \multicolumn{2}{|l|}{4.667} & \\
\hline & & & \multicolumn{2}{|c|}{ Total } & 196.000 & & 48 & & & \\
\hline
\end{tabular}

Source: Author's calculation.

Table 4 displays the quick ratio of Islamic banks in Bangladesh and the comparison among them. It is found that the mean quick ratio of Al ArafahIslami Bank Limited (AAIBL), ShahjalalIslami Bank Limited (SJIBL), Social Islami Bank Limited (SIBL), First Security Islami Bank Limited (FSIBL), ICB Islami Bank Limited (ICBIBL), Islami Bank Bangladesh Limited (IBBL), and Export Import Bank of Bangladesh Limited (EXIM) Bank Ltd are 2.68, 0.87, $0.77,0.49,0.22,0.17$ and 0.10 respectively. The results suggest that most of the Islamic banks have less ability to use their quick assets or near cash assets to retire their liability. This is because they are applying restricted policy of quick asset investment. Standard deviations of quick ratio for the banks lies between 0.09 and 3.22 indicate that variations are relatively lower. However, the findings may also reveal that all Islamic banks are not in a healthy financial position in terms of quick ratio. No difference is found among the Islamic banks in Bangladesh based on ANOVA results.

Table 4: Quick ratios of Islamic Banks in Bangladesh

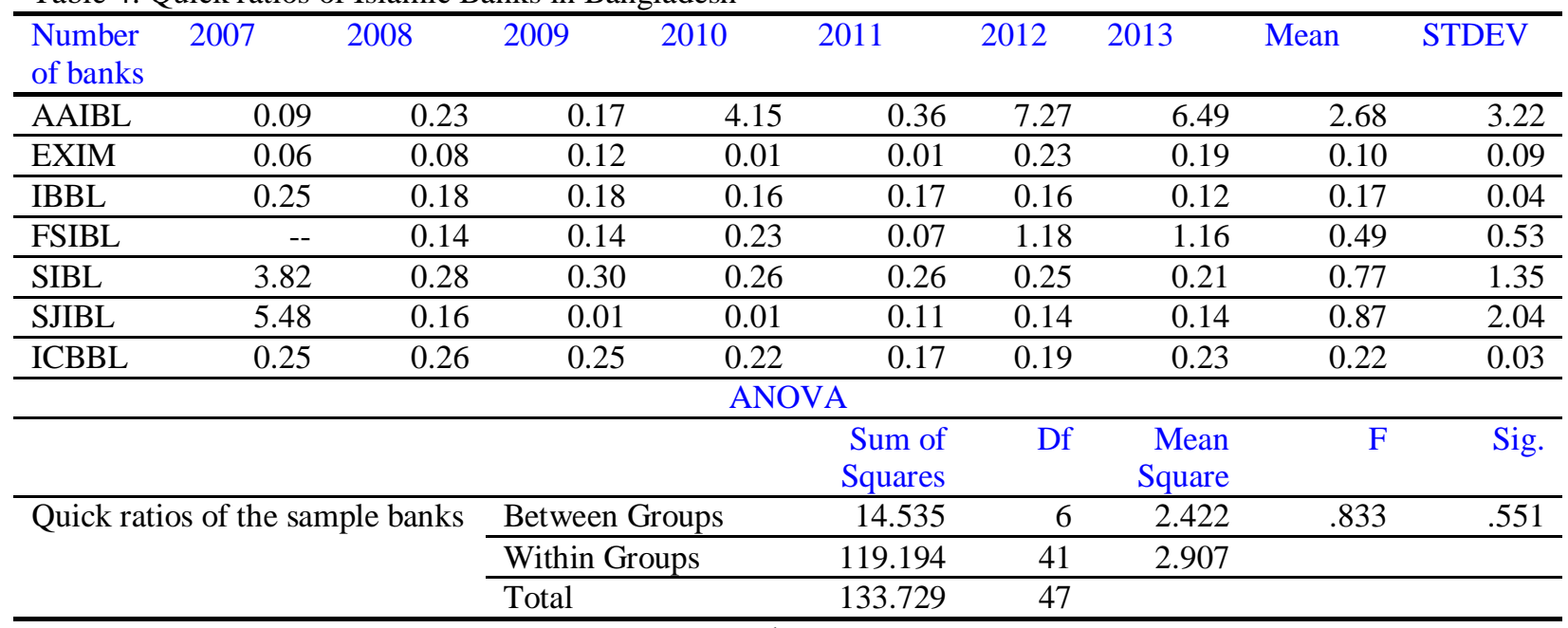

Source: Author's calculation

Table 5 provides the cash ratio of Islamic banks in Bangladesh and the comparison among them using ANOVA. The results find that AAIBL is in the top position among the Islamic banks in Bangladesh based on the mean cash ratio (1.73) followed by SIBL (0.59) and SJIBL (0.38) respectively. The average cash ratios $(0.08 \leq \mu \leq 1.73)$ suggest that Islamic banks in Bangladesh maintain low amount of cash and cash equivalents to meet their current liabilities. Their standard deviations (vary from 0.02 to 2.09 over the seven years periods) reveals that the banks are bearing high risk in short-term solvency. The results also support the findings of Olson and Zoubi (2008) who argued that Islamic banks have more cash relative to deposits. Like the current and quick ratios, sampled Islamic banks in 
Bangladesh have no variation in cash ratio, thus, no significant different among the Islamic banks. This may mean that all Islamic banks may have high risk, according to ANOVA results.

Table 5: Cash ratios of Islamic Banks in Bangladesh

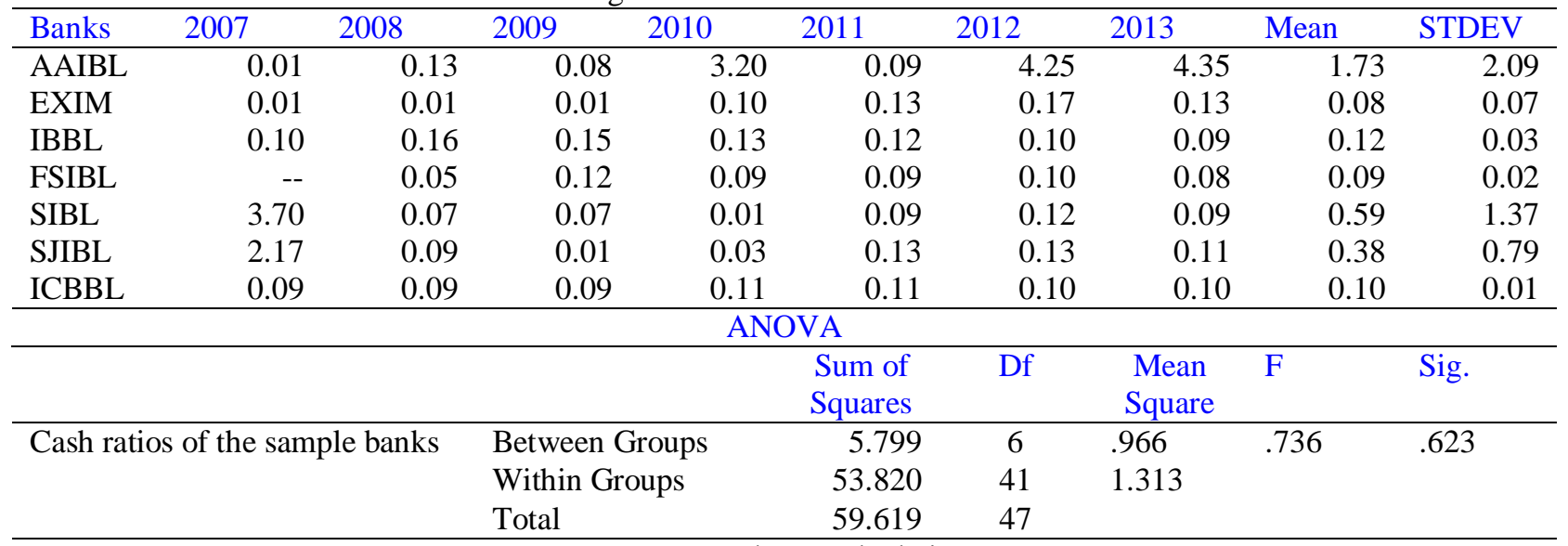

Source: Author's calculation

Table 6 shows the receivable turnover of Islamic banks in Bangladesh and the comparison among the islamic banks using ANOVA test. The results show that AAIBL (on average 16.83) manitains high receivable turnover compare to other islamic banks in bangladesh over the period 2007 to 2013. A part from AAIBL, IBBL (10.61) and EXIM (9.19) banks having reasonably good receivable turnover. This reflects that AAIBL, IBBL ans EXIM banks can use their assets efficiently. On the other hand, FSIBL (0.5), SIBL (1.57), SJIBL (0.65), and ICBIBL (0.81) maintain low value of receivable turnover indicating that these banks are providing more credits to their clients without managing credits in an efficient manner. Thus, it is necessary for FSIBL, SIBL, SJIBL and ICBIBL to reduce the laxity while managing receivable in particular. There is no significant difference in receivable turnover among the Islamic banks in Bangladesh based on the ANOVA results. This suggests that Islamic banks in Bangladesh are homogenous and maintaining the same receivable turnover ratio pattern except for few banks.

Table 6: Receivables Turnover of Islamic Banks in Bangladesh

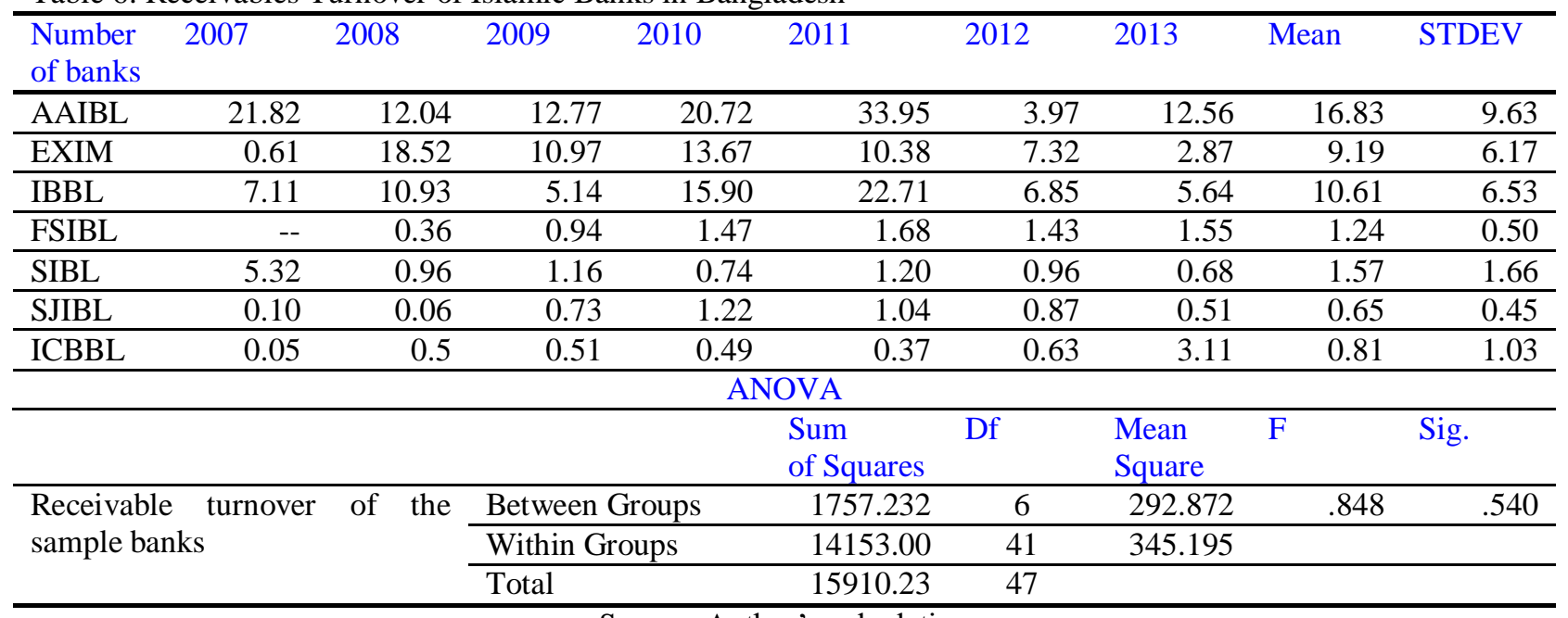

Source: Author's calculation

Overall, it may be reasonably good to argue that the Islamic banks in Bangladesh are homogenous, however, they are not financially healthy when liquidity measurements are concerned. Similar with the study of Olson and Zoubi (2008), Islamic banks have enough cash in their hand but not able to utilise their assets in an efficient way except for AAIBL, IBBL and EXIM banks. This indicates that working capital management of Islamic banks in Bangladesh is not at the optimum level if conventional parameters are considered.

Table 7 shows the results of total debt ratio of Islamic banks in Bangladesh and the comparison among the Islamic banks using ANOVA test. The findings show that the average debt ratios over the period of 2007 to 2013 of AAIBL, 
EXIM, IBBL, FSIBL, SIBL, SJIBL, and ICBIBL banks are 85\%, 91\%, 94\%, 94\%, 89\%, $92 \%$ and $118 \%$ respectively. Interestingly, the results revealed that most of the Islamic Banks in Bangladesh are practicing debtbased financing rather than equity-based financing. Thus, the leverage attributes for an Islamic bank are the same as those for a conventional bank. This can be explained by the several factors. Firstly, a lack of autonomous body to oversee the Shariah compliance of Islamic banks in Bangladesh. Secondly, there is no separate regulatory and institutional systems for Islamic banking practice who can share the experience and promote truly innovative, competitive and Shariah based Islamic banking practice in Bangladesh (Khan \& Bhatti, 2008). In addition to capital structure, there is no significant difference among the Islamic banks in Bangladesh as of ANOVA results.

Table 7: Total Debt ratios of Islamic Bank in Bangladesh

\begin{tabular}{|c|c|c|c|c|c|c|c|c|c|}
\hline $\begin{array}{l}\text { Number } \\
\text { of banks }\end{array}$ & 2007 & 2008 & 2009 & 2010 & 2011 & 2012 & 2013 & Mean & STDEV \\
\hline AAIBL & 0.93 & 0.93 & 0.92 & 0.58 & 0.79 & 0.89 & 0.92 & 0.85 & 0.13 \\
\hline EXIM & 0.92 & 0.93 & 0.92 & 0.89 & 0.89 & 0.90 & 0.89 & 0.91 & 0.02 \\
\hline IBBL & 0.94 & 0.94 & 0.94 & 0.95 & 0.94 & 0.93 & 0.93 & 0.94 & 0.01 \\
\hline FSIBL & -- & 0.92 & 0.94 & 0.94 & 0.95 & 0.96 & 0.96 & 0.94 & 0.01 \\
\hline SIBL & 0.67 & 0.94 & 0.91 & 1.00 & 0.89 & 0.91 & 0.91 & 0.89 & 0.10 \\
\hline$\overline{\text { SJIBL }}$ & 0.95 & 0.92 & 0.92 & 0.91 & 0.93 & 0.93 & 0.91 & 0.92 & 0.01 \\
\hline ICBBL & 0.77 & 0.77 & 0.77 & 1.31 & 1.42 & 1.57 & 1.65 & 1.18 & 0.40 \\
\hline \multicolumn{10}{|c|}{ ANOVA } \\
\hline & & & & \multicolumn{2}{|c|}{$\begin{array}{r}\text { Sum of } \\
\text { Squares } \\
\end{array}$} & Df & $\begin{array}{l}\text { Mean } \\
\text { Square }\end{array}$ & $\mathrm{F}$ & Sig. \\
\hline \multirow{3}{*}{\multicolumn{3}{|c|}{$\begin{array}{l}\text { Total debt ratios of the sample } \\
\text { banks }\end{array}$}} & \multicolumn{2}{|c|}{ Between Groups } & 26.723 & 6 & 4.454 & 1.076 & .393 \\
\hline & & & \multirow{2}{*}{\multicolumn{2}{|c|}{$\begin{array}{l}\text { Within Groups } \\
\text { Total }\end{array}$}} & 169.764 & 41 & 4.141 & & \\
\hline & & & & & 196.487 & 47 & & & \\
\hline
\end{tabular}

Source: Author's calculation

Table 8 displays the findings of fixed asset turnover ratio of Islamic banks in Bangladesh and the comparison among the Islamic banks using ANOVA test. The result suggests that the performance of EXIM bank (8.78) in terms of fixed asset turnover ratio is higher than other Islamic banks in Bangladesh. With the exception of ICBIBL, all the Islamic banks somehow utilise their fixed assets to generate income, but unefficeintly as the ratios are not up to the mark while considering conventional benchmark. It indicates that islamic banks in bangladesh are facing capital budgeting problem. The findings are different with the study of Bellalah (2013) who studied on Islamic banks in Pakistan found on average the fixed asset turnover ratio is $20 \%$. Additionally, since the Islamic banks are homogenous in Bangladesh, the ANOVA test did not find any signIslamic bankscant difference among the Islamic banks.

Table 8: Fixed Asset Turnover Ratio of Islamic Banks in Bangladesh

\begin{tabular}{lrrrrrrrrr}
\hline $\begin{array}{l}\text { Number } \\
\text { of banks }\end{array}$ & 2007 & 2008 & 2009 & 2010 & 2011 & 2012 & 2013 & Mean & STDEV \\
\hline AAIBL & 3.58 & 3.17 & 3.41 & 4.92 & 4.47 & 1.99 & 1.97 & 3.36 & 1.12 \\
\hline EXIM & 9.51 & 8.58 & 8.33 & 12.71 & 8.45 & 12.32 & 1.55 & 8.78 & 3.68 \\
\hline IBBL & 0.95 & 1.44 & 1.00 & 1.25 & 1.46 & 0.80 & 0.70 & 1.09 & 0.30 \\
\hline FSIBL & -- & 1.03 & 1.99 & 2.10 & 1.62 & 0.96 & 0.81 & 1.42 & 0.56 \\
\hline SIBL & 0.29 & 0.80 & 1.12 & 1.24 & 0.89 & 1.22 & 0.76 & 0.90 & 0.33 \\
\hline SJIBL & 0.47 & 14.24 & 3.29 & 2.40 & 1.97 & 1.53 & 0.91 & 3.55 & 4.81 \\
\hline ICBBL & 0.05 & 0.05 & 0.05 & 0.05 & 0.02 & 0.06 & 0.24 & 0.07 & 0.07 \\
\hline \multicolumn{7}{c}{} \\
\hline
\end{tabular}

Source: Author's calculation

Table 9 summarises the results of profit margin of Islamic banks in Bangladesh and the comparison among the Islamic banks using ANOVA test. The results find that the average profit margins $(\mu)$ of AAIBL, EXIM Bank Ltd, 
IBBL, FSIBL, SIBL, SJIBL, and ICBIBL are 4.57\%, 2.13\%, 38.64\%, 44\%, $53 \%, 13.30 \%$ and $5.20 \%$ respectively. Interestingly, SIBL is performing higher that other Islamic banks over the period of 20017 to 2013 based on profit margin. Besides, FSIBL and IBBL are in a good profitable position after SIBL while EXIM, AAIBL and ICBIBL are not in a satisfied position. Thus, the results suggest that most of the Islamic banks in Bangladesh are facing highoperating cost due to the inefficiency of managerial skills and inefficient utilisation of resources (Gitman, 1994).

Table 9: Profit margin ratios of Islamic Banks in Bangladesh (in percentage)

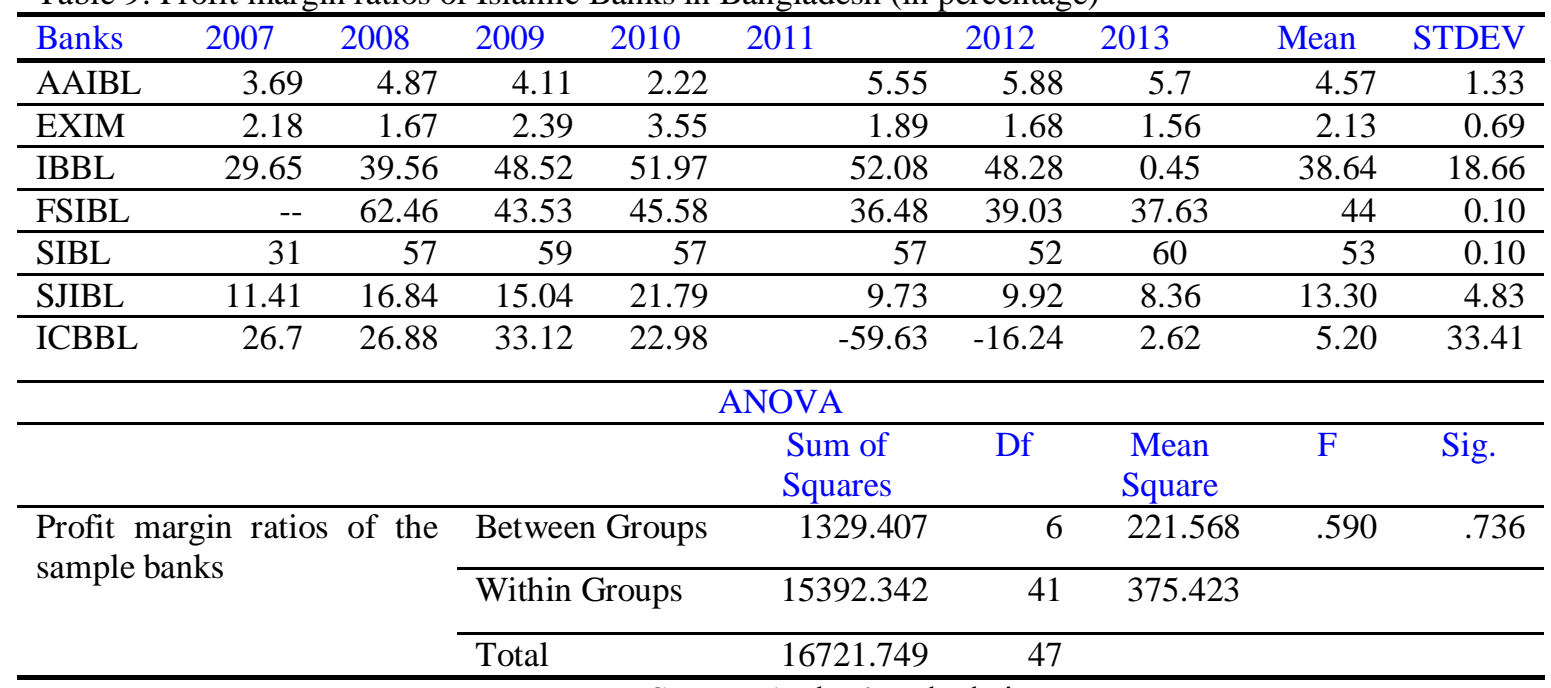

Source: Author's calculation

Table 10 shed lights the results of return on assets of Islamic banks in Bangladesh and the comparison among the Islamic banks using ANOVA test. The findings show that on average the return on assets (ROA) of Islamic banks in bangladesh are between -0.08 to 1.95 . SJIBL (1.95) has the highest ROA ratio followed by EXIM (1.76) and AAIBL (1.70). On the other hand, ICBIBL (-0.08) has the lowest ROA ratio. The outcome indicates that ICBIBL is facing systematic financial crisis. The standard deviations $(0.02 \leq 0 \leq 1.18)$ indicate that the variations of the ROA are in the tolerance level over the period of 2007 to 2013. The overall ROA results are similar with the study of Nabi et al. (2015) who found that ROA of the Islamic banking industry in Bangladesh was 0.89 compared with the overall banking industry of 0.90 in 2013.Based on the ROA, there is no significant difference among the Islamic banks in Bangladesh in ANOVA test.

Table 10: Return on assets of Islamic banks in Bangladesh

\begin{tabular}{|c|c|c|c|c|c|c|c|c|c|}
\hline Banks & 2007 & 2008 & 2009 & 2010 & 2011 & 2012 & 2013 & Mean & STDEV \\
\hline AAIBL & 1.15 & 1.8 & 1.77 & 2.65 & 2.06 & 1.3 & 1.2 & 1.70 & 0.54 \\
\hline EXIM & 1.81 & 1.6 & 1.97 & 3.07 & 1.55 & 1.29 & 1.06 & 1.76 & 0.65 \\
\hline IBBL & 0.84 & 1.27 & 0.01 & 0.01 & 0.01 & 0.01 & 0.96 & 0.44 & 0.56 \\
\hline FSIBL & -- & 0.38 & 0.68 & 0.86 & 0.64 & 0.59 & 0.47 & 0.60 & 0.17 \\
\hline SIBL & 1 & 1 & 1.24 & 2.39 & 2.72 & 2.75 & 1.67 & 1.54 & 1.18 \\
\hline SJIBL & 2.6 & 2.22 & 2.08 & 3.01 & 1.26 & 1.44 & 1.02 & 1.95 & 0.73 \\
\hline ICBBL & -0.08 & -0.08 & -0.11 & -0.07 & $\begin{array}{ll}-0.1 \\
\end{array}$ & -0.07 & -0.05 & -0.08 & 0.02 \\
\hline \multicolumn{10}{|c|}{ ANOVA } \\
\hline & & & & & $\begin{array}{c}\text { Sum of } \\
\text { Squares }\end{array}$ & Df & $\begin{array}{l}\text { Mean } \\
\text { Square }\end{array}$ & $\mathrm{F}$ & Sig. \\
\hline \multirow{3}{*}{$\begin{array}{l}\text { Return on } \\
\text { banks }\end{array}$} & \multirow{3}{*}{\multicolumn{2}{|c|}{ assets of the sample }} & \multicolumn{2}{|c|}{ Between Groups } & 2.394 & 6 & .399 & .346 & .908 \\
\hline & & & \multicolumn{2}{|c|}{ Within Groups } & 47.297 & 41 & 1.154 & & \\
\hline & & & Total & & 49.691 & 47 & & & \\
\hline
\end{tabular}

Source: Author's calculation

The findings of return on equity of Islamic banks in Bangladesh and the comparison among the Islamic banks using ANOVA test are summarised in Table 11. Over the period of 2007 to 2013, the mean return on equity (ROE) of AAIBL, EXIM Bank Ltd, IBBL, FSIBL, SIBL, SJIBL, and ICBIBL are 18.84\%, 19.46\%, 15.68\%, 11.30\%, 9.19\%, $20.05 \%$ and $-7 \%$ respectively. As expected, the ROE of the banks is higher than the ROA. The low fluctuated 
standard deviations $(0.03 \leq 0 \leq 30.45)$ of the ROE over the periods indicate the stability of ROE in the Islamic banks in Bangladesh. With the exception of ICBIBL, overall Islamic banks are having high return on equity ratio suggesting that the resource management of the banks are both efficient and effective. The results are similar withNabi et al. (2015) where they found that the average ROE of Islamic banks in Bangladesh is 11.71 percent in 2013, which is higher than that of the overall banking industry ROE of 10.70 percent in 2013. Furthermore, the results of this study reveal that Islamic banks in Bangladesh have ability to attract future investors. Based on the ANOVA result, no significant difference of ROE is found among the Islamic banks in Bangladesh.

Table 11: Return on equity of Islamic banks in Bangladesh

\begin{tabular}{|c|c|c|c|c|c|c|c|c|c|}
\hline Banks & 2007 & 2008 & 2009 & 2010 & 2011 & 2012 & 2013 & Mean & STDEV \\
\hline AAIBL & 17.05 & 24.7 & 24.1 & 20.01 & 18.34 & 14 & 14 & 18.84 & 4.42 \\
\hline EXIM & 23.03 & 21.98 & 25.22 & 27.86 & 13.87 & 12.97 & 11.31 & 19.46 & 6.62 \\
\hline IBBL & 13 & 19.02 & 16.93 & 19 & 17.42 & 13.42 & 11 & 15.68 & 3.19 \\
\hline FSIBL & -- & 4.66 & 11.41 & 13.99 & 12.75 & 13.33 & 11.63 & 11.30 & 0.03 \\
\hline SIBL & 9 & 11 & 12.14 & 15.31 & 11.51 & 14.15 & 11.01 & 9.19 & 6.39 \\
\hline SJIBL & 18.89 & 23.56 & 25.1 & 30.71 & 13.8 & 17.01 & 11.25 & 20.05 & 6.81 \\
\hline ICBBL & -35 & -36 & -46 & 23 & 24 & 12 & 07 & -07 & 30.45 \\
\hline \multicolumn{10}{|c|}{ ANOVA } \\
\hline & & & & & $\begin{array}{l}\text { Sum of } \\
\text { Squares }\end{array}$ & Df & $\begin{array}{c}\text { Mean } \\
\text { Square }\end{array}$ & $\mathrm{F}$ & Sig. \\
\hline \multirow{3}{*}{\multicolumn{3}{|c|}{$\begin{array}{l}\text { Return on equity of the sample } \\
\text { banks }\end{array}$}} & \multicolumn{2}{|c|}{ Between Groups } & 126.441 & 6 & 21.074 & .205 & .973 \\
\hline & & & \multicolumn{2}{|c|}{ Within Groups } & 4215.731 & 41 & 102.823 & & \\
\hline & & & \multicolumn{2}{|c|}{ Total } & 4342.172 & 47 & & & \\
\hline
\end{tabular}

Source: Author's calculation

\section{Conclusion}

For Islamic banking - it may be reasonably good to argue that the Islamic banks in Bangladesh are homogenous; however, they are not financially healthy when liquidity measurements are concerned. This indicates that working capital management of Islamic banks in Bangladesh is not at the optimum level if conventional parameters are considered. Therefore, it is critical for the Islamic banks to manage their working capital efficiently and they should increase the amount of working capital as much as possible. On the basis of working capital management, no significant difference found among the sampled Islamic banks.

From the evaluation of capital structure efficiency, the results revealed that most of the Islamic Banks in Bangladesh are practicing debt-based financing rather than equity-based financing. Thus, the leverage attributes for an Islamic bank are the same as those for a conventional bank. In addition to capital structure, there is no significant difference among the Islamic banks in Bangladesh.

In case of capital budgeting efficiency, most of the Islamic banks somehow utilise their fixed assets to generate income, but inefficiently as the fixed asset turn over ratios are not up to the mark while considering conventional benchmark. It indicates that Islamic banks in Bangladesh are facing capital budgeting problem. Additionally, since the Islamic banks are homogenous in Bangladesh, the result did not find any significant difference among the Islamic banks.

The findings of overall Islamic bank financial management's operating efficiency suggest that most of the Islamic banks in Bangladesh are facing high-operating cost due to the inefficiency of managerial skills and inefficient utilization of resources. However, based on the return on equity, it is suggested the resource management of the banks are both efficient and effective and the earnings of Islamic banks are higher as compared to their equity position. Similarly, no significance difference found among the Islamic banks.

The study has put forward an important question by analyzing IFM practices in Bangladesh and derived several conclusions based on the findings. Best on the author's knowledge, this study is one of the few that has comprehensively investigated the issue from a single country perspective. While the study has observed that the practices of IFM in Bangladesh are promising, however, there are numerous challenges encroaching the industry. Hence, immediate attention from the respective authorities, including practitioners and policy makers are indeed vital. In that aspect, establishing an independent regulatory authority to supervise and monitor the activities of Islamic should be prioritized in the government agenda. This would ensure and create more congenial infrastructure for the smooth functioning of IFM practices of Islamic banks in Bangladesh. 


\section{References}

Abu-Tapanjeh, A. M. (2009). Corporate governance from the Islamic perspective: A comparative analysis with OECD principles. Critical Perspectives on accounting, 20(5), 556-567.

Akkizidis, I., \&Khandelwal, S. (2007). Financial risk management for Islamic banking and finance.Springer.

Ather, S. M. (2007). Islamic Management and Business. Chittagong: Noksha Publications.

Akkas.S.M., (2008). Problems and prospects of Islamic Banking. Text Book on Islamic Banking, Islamic Economics Research Bureau, Dhaka, Bangladesh

Bangladesh Bank (2016). Annual report of 2016. Retrieved from www.bb.gov.bd

Bangladesh Bank (2017). Annual report of 2017. Retrieved from www.bb.gov.bd

Dhaka Tribune (2018). 230,000 loan defaulters in the country, Muhith tells parliament. Available at, https://www.dhakatribune.com/bangladesh/nation/2018/09/13/230-000-loan-defaulters-in-the-countrymuhith-tells-js

Erol, C., \& El-Bdour, R. (1989). Attitudes, Behavior and Patronage Factors of bank Customers towards Islamic Banks. International Journal of Bank Marketing, 7 (6), 31-39.

Fiennes, T. (2007).Supervisory implications of Islamic banking: A supervisor's perspective. Islamic finance: the regulatory challenge, $247-256$

Gitman, L. J. (1994). Principles of Managerial Finance (7th Ed). Harper Collins

Iqbal, M., Aḥmad, A., \& Khan, T. (1998).Challenges facing Islamic banking.Islamic Research and Training Institute.

Khan, M., \& Bhatti, I. M. (2008). Islamic banking and finance: on its way to globalization. Managerial finance, 34(10), 708-725.

Khan, M. M. (1989).The Translation of the Meaning of Sahil Al- Bhukhari (Vol. 3). Lahore: Kazi Publications.

Khan, T., \& Ahmed, H. (2001).Risk management: an analysis of issues in Islamic financial industry. Islamic Development Bank, Islamic Research and Training Institute.

Laldin, M. A. (2008). Fundamentals and practices in Islamic finance (Vol. 1). International Shari'ah Research Academy for Islamic Finance.

Mohiuddin, M. G. (2004). Islamic Management. Dhaka: The University Grants Commission of Bangladesh Publishers.

Nabi, M. G., Islama, M. A., Bakarb, R., \&Akterc, A. (2015). Islamic Banking in Bangladesh: Current Status, Challenges and Policy Options.

Oseni, U. A., \& Hassan, M. K. (2012). The dispute resolution framework for the Islamic capital market in Malaysia: Legal obstacles and options. Islamic capital markets: Products and strategies, 91-114.

Olson, D., \&Zoubi, T. A. (2008).Using accounting ratios to distinguish between Islamic and conventional banks in the GCC region.The International Journal of Accounting, 43(1), 45-65.

SudinHaron\& Wan Nursofiza wan Azmi, (2009), "Islamic Finance and Banking System-Philosophyies, principles and Practices", Mcgrow Hill Education, p-47.

Sundararajan, V., \&Errico, L. (2002). IFI and products in the global financial system: Key issues in risk management and challenges ahead (Vol. 2). International Monetary Fund.

The Financial Express (2018). Call to frame Islamic banking law. Available at, http://thefinancialexpress.com.bd/economy/bangladesh/call-to-frame-islamic-banking-law-1528170729

Usmani, M. Taqi,(1998), Sukuk and their Contemporary Applications, AAOIFI Shariah Council, P-2.

\section{Copyrights}

Copyright for this article is retained by the author(s), with first publication rights granted to the journal.

This is an open-access article distributed under the terms and conditions of the Creative Commons Attribution license (http://creativecommons.org/licenses/by/4.0/) 